\title{
Membranes, molecules and biophysics: enhancing monocyte derived dendritic cell (MDDC) immunogenicity for improved anti-cancer therapy
}

\author{
Cyril Rauch, Hiba Ibrahim and Neil Foster \\ *Correspondence: n.foster@nottingham.ac.uk \\ School of Veterinary Medicine and Science, University of Nottingham, UK.
}

\begin{abstract}
Despite great medical advancement in the treatment of cancer, cancer remains a disease of global significance. Chemotherapeutics can be very expensive and drain medical resources at a national level and in some cases the cost of treatment is so great that it prohibits their use by local health authorities. Drug resistance is also a major limiting factor to the successful treatment of cancer with many patients initially responding well but then becoming refractory to treatment with the same drug and in some case may become multi-drug resistant. The immune system is known to be important in the prevention of tumors by eliminating pre-cancerous or cancerous cells. This concept of immune surveillance has largely been super-ceded by the concept of immunoediting whereby the immune system imposes a selective pressure on tumor cells which may either control tumor growth or inadvertently select for tumor cells which have evolved to escape the immune response and which may induce tumor development. Stimulation of the immune system by vaccination offers many benefits in the treatment of cancer. It is highly cost effective and vaccines can be manipulated to include multi-antigens which in some cases may overcome equilibrium (and selective pressure) while also preventing the establishment of reactivated cancer cells, since cancer antigen-specific memory would be induced following the initial vaccination/booster phase. To date studies using vaccination as a treatment for cancer have been a little disappointing, probably due to insufficient level of immunogenicity. In this review we will discuss methods of manipulation of the immune system to increase the anti-cancer activity of dendritic cells in vivo and how monocyte derived dendritic cells may be manipulated ex vivo to provide more robust, patient-specific treatments.
\end{abstract}

Keywords: Dendritic cell, MDDC, vaccine, immunogenicity

\section{Review}

\section{The global impact of cancer}

Although new chemotherapeutics and greater diagnostic modalities have been developed, cancer remains a disease of global significance. There are around 12.7 million cases of cancer globally per year and this is estimated to increase to 26 million per year by 2030 [1]. In 2010, 324,579 cases of Cancer were diagnosed in the UK and 157,275 deaths due to cancer were recorded [2]. The enormous cost of the disease suffered by governments and healthcare providers undoubtedly negatively impacts on other areas of health spending and in many cases newly developed drugs are too expensive for health authorities to purchase. The cost has been estimated to increase from $£ 30000$ to $£ 40000$ per patient per year between 2010 and 2021 [3]. Furthermore, there is significant emerging resistance in many cases to chemotherapy [2], and a wealth of research has now been published which has shown the various mechanisms, detection and amelioration of resistance [4-9] by tumours to chemothereutic drugs. In the developing world many cancers remain untreated, due simply to the financial burden of current treatments, even more significant when considering that current global estimations of 12.7 million new cases of cancer per year are predicted to increase to 26 million per year by 2030 [1]. Less expensive and effective new treatments would, therefore, be of obvious benefit in both the developed and developing world.

The concept of 'immuno-surveillance' in cancer biology is not new, and suggests that the immune response largely keeps in check the development of tumours. The development of efficient cancer vaccines therefore would appear to be a rational and cost effective therapeutic approach to the treatment of cancer.

The role of dendritic cells in adaptive immunity and vaccination

Antigen presenting cells (APCs) bridge the gap between innate and adaptive immunity, since APCs are innate immune cells which present antigens to the adaptive immune system ( $T$ and B lymphocytes). All APCs express major histocompatibility complex II (MHCII) as well as $\mathrm{MHCl}$ on their cell membranes, either constitutively or when activated. Antigen presentation to lymphocytes also requires a second (co-stimulatory signal) provided by molecules such as CD40, CD80 and CD86 which 
Rauch et al. Journal of Cancer Therapeutics \& Research 2013,

engage with their counterparts (CD40 ligand and CD28) on the surface of T lymphocytes. The extent to which these molecules are expressed on the surface of APCs is paramount to the induction of a robust lymphocyte response to antigen. Another factor which may influence the lymphocyte response is the number of lymphocytes, with cognate T cell receptors, which can engage antigen on the APC surface and the most effective APCs have large surface areas due to membrane folding or cellular extensions (pseudopodia).

Amongst APCs, only dendritic cells (DCs) have the ability to present antigens to naïve $T$ lymphocytes [10-11] and $B$ lymphocytes [12] and the amount of antigen presented by DCs is orders of magnitude greater than can be presented by macrophages [13]. DCs are therefore essential in the development of adaptive immunity and as such are important targets for vaccine antigens and adjuvants. In humans, DCs exist as a number of different sub-populations. These include Langerhans cells (LCs) and interstitial DCs (iDCs) (found in peripheral tissues), conventional DC (CDCs) which are further subdivided into type 1 and type 2 subsets ( $\mathrm{mDC} 1 / \mathrm{mDC}$ ) and plasmacytoid DCs (pDCs). In addition to these subsets, monocytes can be differentiated into monocyte derived DCs (MDDCs). Previously, the DC activation model suggested that precursors of LCs and iDCs migrate from blood into tissues and remain in an immature form until activated by pathogens or cytokines. Once activated these cells mature as they migrate to the draining lymph node where they present antigens to cognate lymphocytes [14-15]. However, more recent studies have indicated that this model may be too simplistic and that activation of DCs is more tightly controlled than was previously believed. For example a recent study has suggested that migrated rat pseudo-afferent DCs do not mobilize CD40 stores to the cell membrane during interaction with steady state T lymphocytes but do mobilize CD40 to the immune synapse during allogeneic interaction but only for a limited time period [16] and a study by Geissmann [17] has also shown that MHCll stores in human LCs, migrating from inflamed skin into draining lymph nodes, remain cytoplasmic and only low levels of CD86 are detected on the cell membrane. While LCs may actually migrate into embryonic tissue and renew their population in situ, rather than from blood precursors [18] as was previously thought. However human DC populations are controlled in steady state conditions or activated and renewed in vivo, it is clear that much more of the biology of these $D C$ subsets has yet to be revealed. Furthermore, the relative number of circulating DCs is very low with $\mathrm{CDCs}$ representing about $<0.6 \%$ of the total peripheral blood mononuclear cells [19-20] and pDCs representing $<0.4 \%$ [21]. It would not be a viable proposition to obtain DCs for in vitro manipulation (e.g., culturing with tumor antigen) since the numbers obtained would be much too low. With this in mind strategies have been developed which attempt to expand DC populations in vivo or manipulate MDDCs in vitro for replantation into the syngeneic patient (Figure 1).
Expanding DC populations in vivo as a mechanism for increased tumor immunogenicity

Cytokines

Expanding the tumor antigen expressing DC populations would appear to be a rational approach to increasing the immunogenicity of cancer vaccines. One cytokine known to increase DC populations in lymphoid organs is fms-like tyrosine-kinase 3 ligand (Flt-3 ligand) [22-24] and daily administration of Flt-ligand has been shown to induce tumor regression and decrease tumor growth in mice with fibrosarcoma [25]. Flt-3 ligand and CD40 ligand were also shown to synergise to further expand DC numbers in mice with B10.2 or B10.5 tumors and this treatment led to a reduction in tumor growth or, in some cases, complete cure [26]. Flt-3 ligand delivered via particle mediated transfection was also reported to inhibit the growth of MCA205-induced Sarcomas in mice and in this study increased $C D 11 C+C D C s$ were shown in tumor tissues as well as increased CD80 and MHCll expression [27]. Intra-nodal administration of Flt-3 ligand with antigenencoding RNA has also been reported to expand both CDC and PDC populations in a murine melanoma model [28]. In this study Flt-3 ligand and RNA induced expansion of nodal Th1 cells and increased tumor-specific CD8+ lymphocytes via antigen presentation by $\mathrm{pDCs}$. The study also showed that $70 \%$ of mice were cured of tumors following Flt-3 ligand/ RNA inoculation compared with only $11 \%$ cured following inoculation with RNA alone. This suggests that Flt-3 ligand may act as a DC adjuvant and that its inclusion in vaccine formulations may significantly enhance the immunogenicity of cancer vaccines.

Conversely, a study by Taylor et al., [29] has reported that progression of murine myeloproliferative disease (MPD) (induced by inactivating knock-in mutation in the RING finger domain of the $\mathrm{c}-\mathrm{Cbl} \mathrm{E} 3$ ubiquitin) is prevented by treatment with the Flt-3 kinase inhibitor AC220 and continued for as long as AC220 was administered. A study by Greystoke et al., [30] has also indicated that elevated Flt-3 ligand can be used to predict patients who develop neutropenic sepsis following chemotherapy against lymphoma. It is difficult to say whether there was a true causal link in this case but increases in plasma Flt-3 ligand in irradiated non-human primates was shown to be inversely correlated with neutropenia and when peak concentrations subsided this was correlated with a return of total blood cells counts to normal [31]. The treatment of neutropenia usually requires administration of granulocyte-colony stimulating factor (G-CSF) and a more stable form of recombinant G-CSF (Pegfilgrastim) has been developed [32]. Interestingly, administration of Pegfilgrastim to patients with gynaecological malignancies was shown to significantly increase circulating numbers of both $\mathrm{CDCs}$ and pDCs and as well as preventing neutropenic sepsis, caused by chemotherapy or possible future Flt-3 therapy, Pegfilgrastim appears to also expand DC populations in vivo in its own right. Therefore, studies to date have certainly highlighted the 


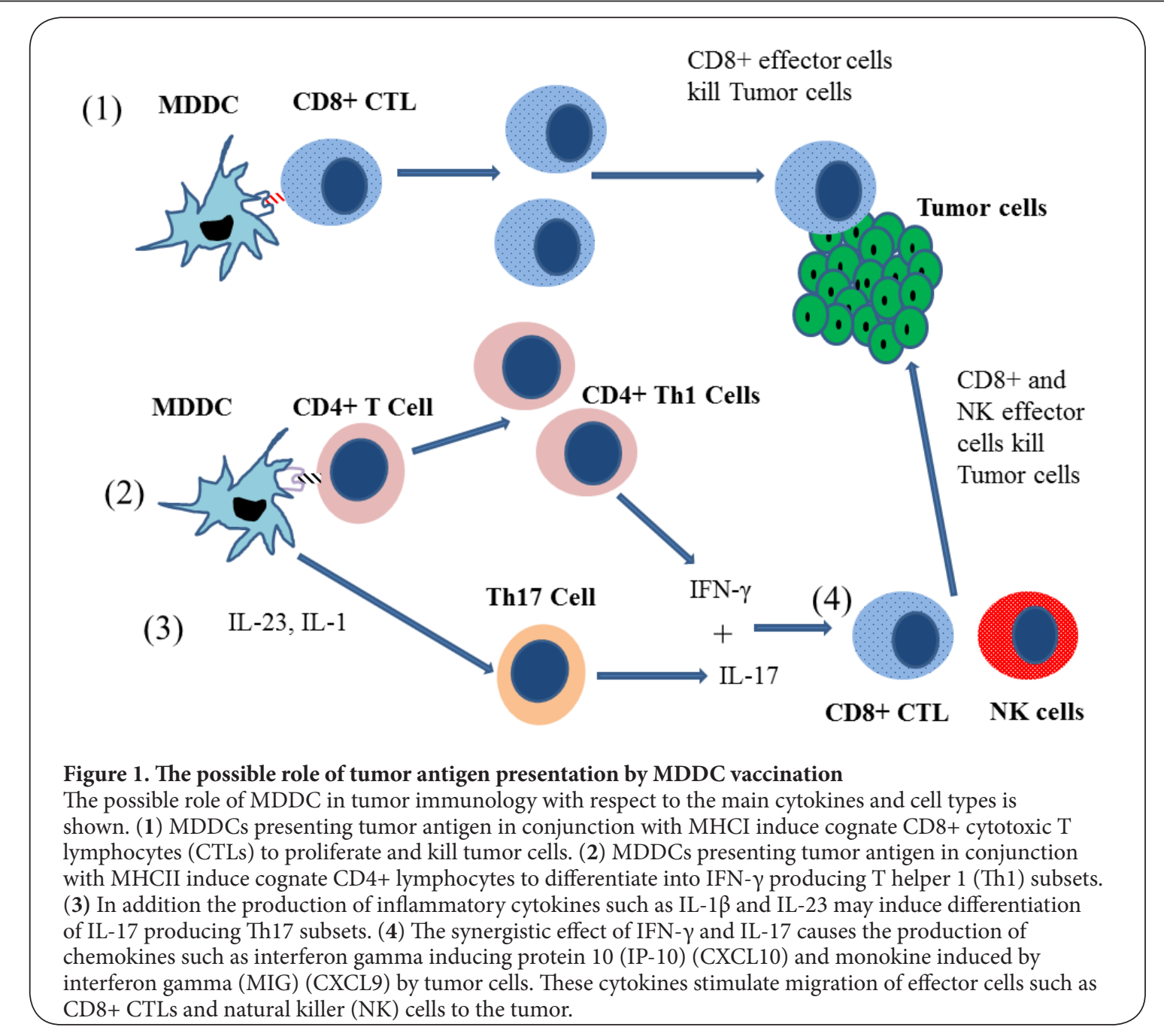

immune-therapeutic potential of Flt-3 ligand in cancer but the use of Flt-3 to increase DC populations in vivo may have some draw-backs which need to be studied more thoroughly.

Although Flt-3 ligand is probably the best studied of molecules which expand DC populations in vivo others cytokines have also been shown to have therapeutic potential. Macrophage inflammatory protein 3 alpha (MIP-3a) is an inflammatory chemokine which binds to CC-chemokine receptor 6 [33]. CCR6 is involved in the peripheral recruitment of immature Langerhands cells but it is CCR7 expression by mature DCs which induces their migration into the T cell areas of lymph nodes. Vaccination of mice with another cytokine granulocyte macrophage colony stimulating factor (GM-CSF) has been shown to have a very potent anti-tumor effect [34] and more recently Choi and Kim, [35] reported that plasmids encoding MIP-3 $a$ and GM-CSF synergistically induced DC recruitment and increased Thelper (Th) cell and cytotoxic T lymphocyte (CTL) activity at the site of murine EML/Muc1 tumors and draining lymph. However, there is also evidence to suggest that tumours may suppress the host immune response via CCR7 expression and that expression of CCR7 may also be involved in metastasis [36], via ligation of the cytokine CCL21 [37]. It is clear therefore that the exact relationship between CCR7 expression, DCs and tumor regression, or indeed progression, needs further clarification.

Hohman et al., [38] were the first to identify a population of murine cells with both Natural killer cell (NK) cell and DC-like properties. These cells were termed NKDCs and later Chan et al., [39] reported that these cells produce IFNY and kill cells expressing tumor antigen. Recently it has been shown that murine splenic NKDCc will proliferate in vitro when cultured with IL-21 and when replaced back into B16F10 (melanoma) tumor bearing C57BL/6 mice, the IL-21-cultured NKDCs were associated with a reduction in tumor size [40]. This may suggest that administration of IL-21 with tumor antigen could increase immunogenicity of cancer vaccines in vivo. However, one study has suggested that NKDCs may actually be a population of activated NK cells [41] and to date a similar NKDC population has not been reported in humans. IL-24 is another cytokine which has come into prominence recently 
and is being investigated for its effect on many different cancers. IL-24 was first shown to be a protein product encoded by the melanoma differentiation-associated gene 7 (mda-7) [42] and was shown to have an anti-cancer effect in a number of human cancerous cell lines, including colorectal, prostate and cervical cancers [43]. Low expression of mda/IL-24 has been associated with increased nodal involvement in human breast cancer [44] and reduced survival of colorectal cancer patients [45]. One mechanism by which mda/IL-24 has anticancer effects is by the promotion of cell death, such as the generation of ceramide, the production of reactive oxygen species and increased ER stress and mda-7 gene transfer via vectors such as adenovirus is currently being investigated [46]. High expression of mda-7 has also been shown in DCs within germinal centres of melanoma patients [47] which may suggest a different mechanism by which DCs suppress tumors via direct suppression rather than presentation of tumor antigens. However, increased expression of molecules essential for antigen presentation (HLA-DR, CD40 and CD80) was also measured in human DCs transfected with IL-24 gene containing adenovirus and pulsed with lysates from SMMC-7721 (human hepatocellular carcinoma cells) [48]. This was also associated with increased production of IL-24, IL-12 and TNF- $a$ and when these DCs were cultured with cytokines induced killer cells (ICK), they stimulated greater lytic activity by ICKs on SMMC-7721 cells. Once again these latter experiments suggest that IL-24 could be an important adjuvant if used in DC vaccines.

\section{Other molecules}

Carthamus tinctorius (CT), or safflower, is used in Chinese traditional medicine to improve blood circulation. A study by Chang et al., [49] has reported that when murine bone marrow derived DCs were cultured with CT extract and pulsed with a JC cell (murine mammary adenocarcinoma) lysate, prior to administration into tumor bearing mice, they reduced tumor mass by $>15 \%$. This was also associated with a skewed Th response towards IFN- $\gamma$-producing Th1 cells and in vivo the CT-DC combination induced proliferation of CD8+ lymphocytes. An earlier study also reported that when CT polysaccharide was administered into mice bearing either S180 Sarcoma or LA795 lung tumors it was associated with a respective tumor inhibition or shrinkage and increased activity of CD8+ lymphocytes and natural killer (NK) cells, although DC activity was not studied [50]. Polyinosinic-cytidylic acid (poly (I:C)) has also been reported to increase DC populations removed from cervical cancer patients and when pulsed with $\mathrm{E} 7$ human papilloma virus antigen they increased surface expression of CD11C and CD86 [51]. It should be noted that although CD11C is a classic marker for myeloid DCs it is also has very important immunological properties. For example CD11C is a receptor for compliment protein iC3b and increases phagocytosis of iC3b-opsonized particles [52], while antibody blockade of CD11C on the surface of LCs ameliorates proliferation of allogeneic T lymphocytes [53], thus indicating a key role in the induction of innate and adaptive immunity. In another study, Poly: IC has also been shown to inhibit metastasis in a B16-F10 murine lung cancer model and was associated with increased DC maturation, increased CD8+ (CTL) activity and skewing of the immune response towards Th1/Th17 [54], while administration of a combination of the synthetic lipopeptide Pam3Cys with Poly: IC induced greater maturation of DCs and conferred tumor protection in mice [55].

\section{The therapeutic potential for Monocyte derived DCs (MDDCs) in patient-specific cancer therapy}

DCs can be derived ex vivo from blood monocytes (MDDCs) and since monocytes represent a large population of blood cells, numerous MDDCs can be derived in culture media containing granulocyte-monocyte colony stimulating factor (GM-CSF) and interleukin 4 (IL-4) [56]. Compared with their autologous monocytes, these MDDCs have increased surface area due to the development of dendrites (Figures 2A and 2B) and express a characteristic surface phenotype in which they express high levels of CD11C, CD83 and CD1a (which are not expressed by monocytes) and increased HLA-DR but very low levels of CD14, which is highly expressed by monocytes (Figures $\mathbf{2 C - 2 G ) . ~ T h e s e ~ i m m a t u r e ~ M D D C s ~ c a n ~ t h e n ~ b e ~ m a t u r e d ~}$ using various other cytokines including, TNF- $\alpha$ and IL-1 $\beta$ [57] while we have recently shown that human MDDCs mature in response to IFN- $\gamma$, IL-1 $\beta$ and novel cytokines, such as IL36 $\beta$ or IL36y, allowing easy measurement of immunological parameters such as further increases in HLA-DR and CD83 with a concurrent decrease in CD1a [58] (Figures 3E-3G). Furthermore, in humans and murine models, MDDCs appear to be a physiological population generated in vivo during inflammation $[\mathbf{5 9}, \mathbf{6 0}]$, possibly serving to replenish spent peripheral DC populations. Autologous MDDCS can be safely injected back into recipients without inducing a host versus DC reaction (as long as utmost sterility can be achieved). This approach could allow patient specific vaccines to be developed according to tumor type and antigen expression. As such, a number of studies have now been reported to show that autologous monocyte derived DCs (MDDCs) preloaded with relevant tumour antigen may be of some benefit in certain cancers [61-63].

Meta-analysis of the first 1000 MDDC vaccinees, with different tumours, demonstrated that about half exhibited a clinical response, and that MDDC vaccination was associated with virtually no adverse effects [64]. In another study, survival of patients with advanced melanoma was increased from 5 months to 24 months following injection of autologous MDDCs loaded with melanoma antigen, and was significantly correlated with increased numbers of IFN $-\gamma$ producing Th1 lymphocytes [65]. It has also been reported [66] that MDDCs pulsed with carcinoembryonic antigen (CEA) induced antigen-specific $T$ cell response in 8 out of 11 patients with colorectal cancer, and that this technique was far superior 


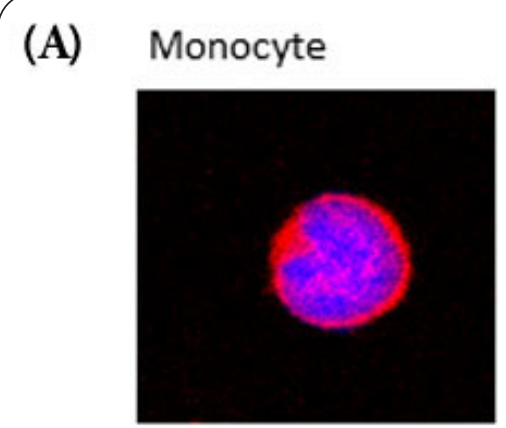

(B) Immature (day 5) MDDC

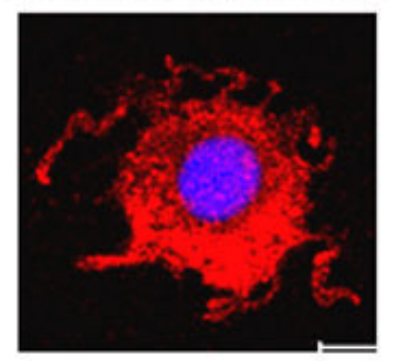

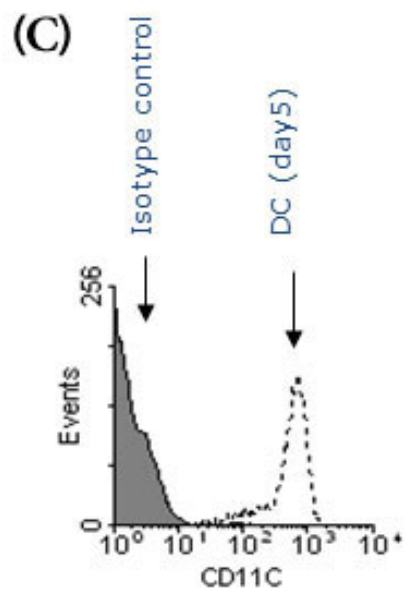

(D)

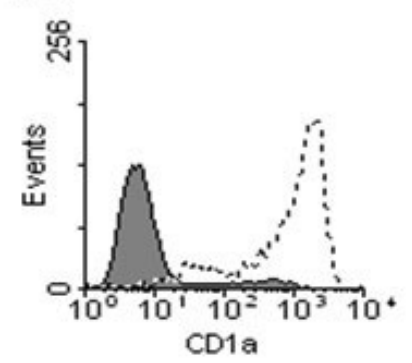

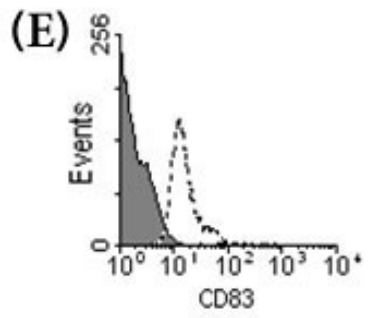

(F)

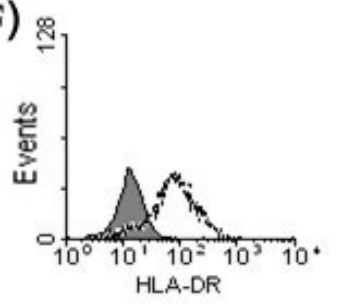

(G)

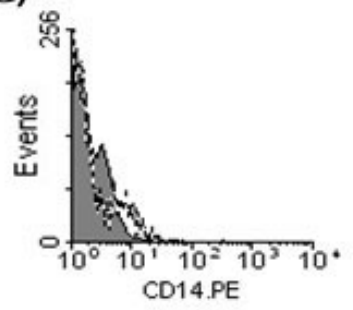

\section{CD11C $^{\text {high }} /$ CD1ahigh $/ C D 14^{\text {low }} /$ HLA-DR $^{\text {high }}$}

Figure 2. IL-4 and GM CSF differentiates human monocytes into monocyte derived dendritic cells (MDDC) in vitro After 5 days culture in IL-4 (10 ng/ml) and GM CSF $(50 \mathrm{ng} / \mathrm{ml})$ for 5 days, human monocytes (A) differentiate into immature MDDCs (B) which are larger and have characteristic dendrites (arrows). MDDCs are also phenotypically distinct from monocytes by expressing high levels of CD11C, CD1a, CD83 and HLA-DR (C-F) but not CD14 (G) on their cell membrane.

to MDDC transfection using CEA mRNA. Phase I clinical trials using the CEA loaded MDDCs in colorectal cancer patients indicated that they induced both a CD4+ and CD8+ effector response, but that $T$ suppressor activity may have impacted on the full effect of the vaccine [67]. MDDCs loaded with CEA and melanoma associated antigen 3 (MAGE-3) induced significant increases in the killing of target cells by CTLs [68]. In a murine model of Melanoma therapy, MAGE-3 pulsed MDDC induced tumour specific CTL responses and inhibited tumour growth [69]. Recent studies have also shown that when mature MDDCs (designed to initiate Th1 cells) were pulsed with HER-2 antigen, they induced a robust IFN- $\gamma$ response in addition to enhanced tumour cell-killing capacity in breast cancer patients. Furthermore, a recall response was measured after 52 months [70]. The data therefore, indicates that tumour antigen loaded MDDCs are a realistic strategy for future cancer therapy. Although DCs have been shown to be important in anti-melanoma immune responses [71] advanced melanoma is normally associated with immune suppression. However, one study has shown that human melanoma-conditioned media had no effect on the maturation of MDDCs, cytokine production (including Th1-inducing IL-12) or T cell proliferation [72]. This may suggest then that MDDC vaccines may be an ideally suited therapy for melanoma. Conversely, expression of Galectin-1 by lung cancr cell lines (A549 andNCl-H460) induces IL-10 producing MDDCs and IL-10-producing CD11C+ cells (DCs) have been shown to populate human lung tumors [73]. Since production of IL-10 by DCs is associated with the differentiation of tolerogenic T cells, the study discussed above may suggest that MDDCs vaccines may have detrimental effects on therapy, although the immune status of MDDCs loaded with lung tumor antigen has not been reported.

By using tumour cell lysates [74], it has been demonstrated that a maximum of $5 \mathrm{mg} / \mathrm{ml}$ lysate can be loaded into $1 \times 10^{6}$ MDDCs, and that a minimum of $1 \mathrm{mg} / \mathrm{ml}$ over a $24 \mathrm{~h}$ culture period is required to produce measurable changes in DC immunogenicity. Such studies are critical to the future success of this strategy since the ability to deliver 1 effective vaccine dose may be necessary, as booster vaccines using tumour 
(A) Isotype control

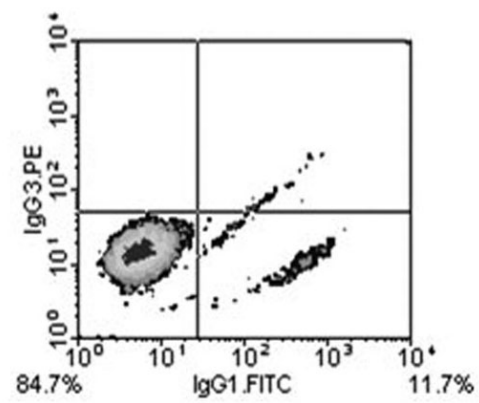

(B) Unstimulated MDDC

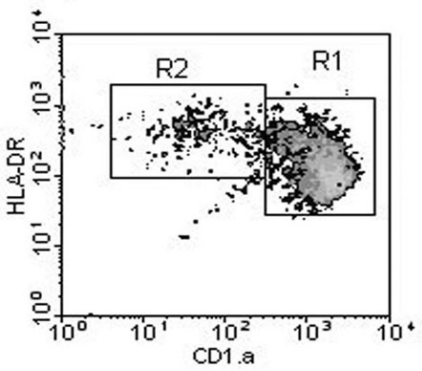

(C) IL-36B

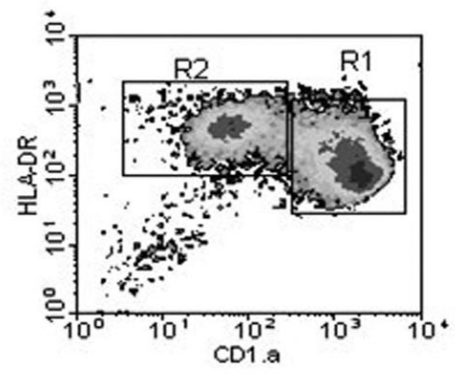

(D) $\mathrm{IL}-36 \gamma$

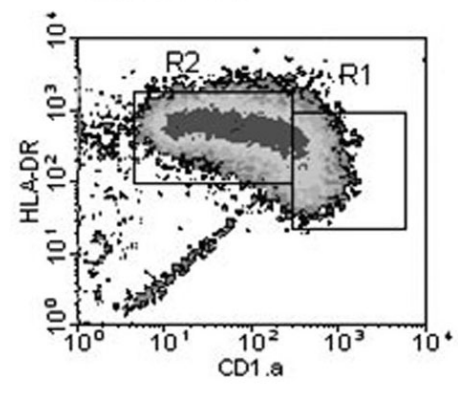

(E) IFN- $\gamma$

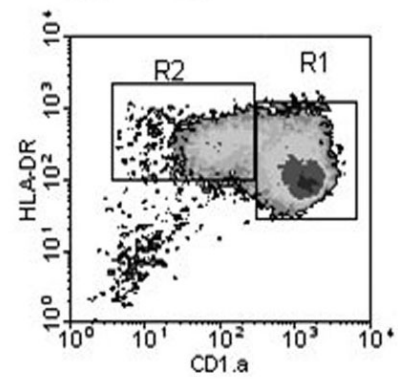

(F) IL-1F2

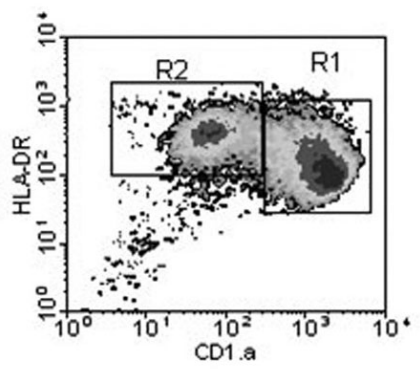

(G) CD83 expression

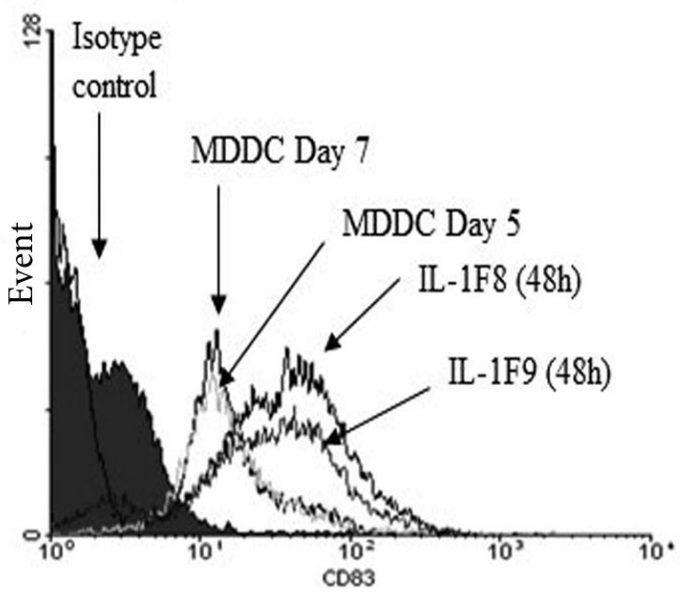

Figure 3. Immature MDDCs can be matured (to increase immunogenicity) by culture with specific cytokines Compared to isotype controls (A) or unstimulated MDDCs cultured over the same time period (B). MDDCs cultured with IFN- $\gamma$, IL-1 $\beta$, IL-36 $\beta$ or IL-36 $\gamma$ for $48 \mathrm{~h}$ exibit further increased expression of HLA-DR and CD83 but decreased expression of CD1a on their cell membranes $(\mathbf{C}-\mathbf{G})$.

loaded MDDCs will be killed by memory CTLs. Although Dhodapkar et al., [75] have reported that a single injection of MDDCs is enough to induce a rapid, antigen specific and broad $T$ cell response in humans and it is possible that that techniques which can boost the immunogenicity of a single injection vaccine will undoubtedly produce a greater clinical effect, and could contribute to overcoming the effect of suppressor activity.

\section{Enhancing MDDC vaccination by adequately engineering} the cell membrane

The membrane is composed of two leaflets which are themselves composed chiefly of lipids and other amphipathic molecules. For a long time these were considered to be neutral, with regard to the complex biochemical processes taking place within cells, but this view has now changed and it is well acknowledged that the lipid phase forming the boundary of cells is at least as important as the biochemistry taking place within cells. How the cell membrane is used by cells has become a much studied field of research and from these studies one can say that the lipid phase of the membrane has two main properties as it: (i) permits the stability required to allow transmembrane proteins to function properly and, (ii) allows exchanges with the extracellular medium via the mechanism of membrane recycling i.e., endocytosis and exocytosis. Both points (i) and (ii) have been shown to rely deeply on the biophysical properties of the cell membrane as well as the ability of cells to biologically control these processes.

What matters in the case of antigen presentation is the potential ability to control membrane exocytosis. Membrane 
(A) Endocytosis/Exocytosis

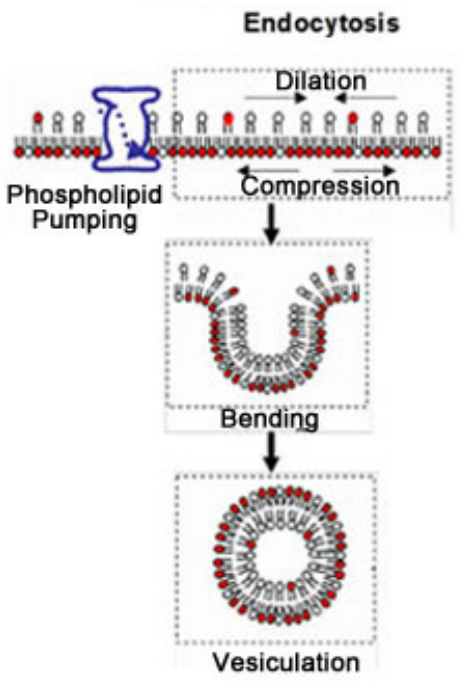

\section{Exocytosis}

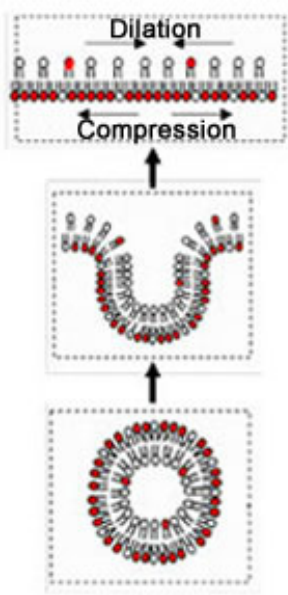

(B) PC mediated exocytosis of GLUT-1 in $\mathrm{C} 2 \mathrm{C} 12$ cells

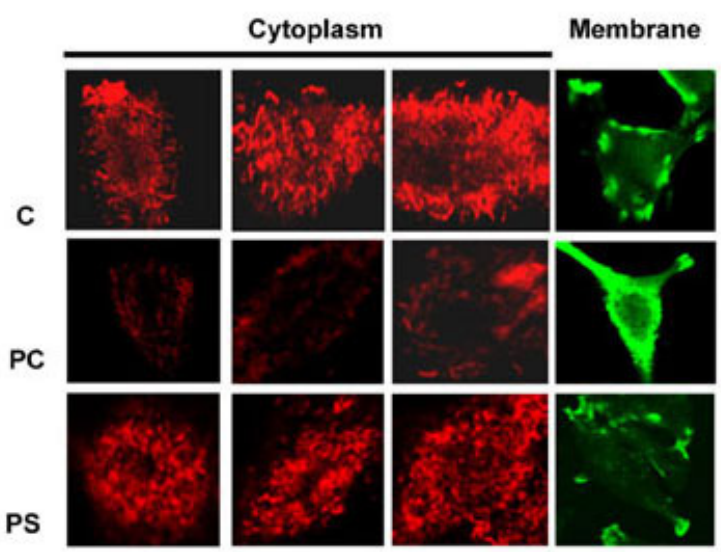

Figure 4. How membrane lipids influence endocytosis and exocytosis

The lipid number asymmetry induced fluid phase endocytosis : Sketch representing the current model that has been applied to living cells, links fluid phase endocytosis (A) and the membrane phospholipid number asymmetry maintained by a lipid flippase (the aminophospholipid translocase). In the left figure, the translocation of dark-head lipids into the inner leaflet induces a differential lipid packing between leaflets (namely a difference in surface pressures) leading to membrane bending and vesiculation. Note that it is assumed that the membrane recycling that occurs in cells, i.e., the exocytosis of vesicles of a size similar to endocytic vesicles (B), also allows the maintenance of the lipid asymmetry at the level of the plasmalemma. The relationship between the lipid number asymmetry and the vesicle radius can be determined fully considering the physical biology of the cell membrane see ref (75). A fundamental consequence resulting from the theory is that if the lipid asymmetry is inverted (i.e., if the outer leaflet contains more lipid than the inner leaflet) exocytosis should be promoted to balance the membrane stress. This was demonstrated by Rauch and Loughna (2005) using phosphatidylcholine (PC) as a phospholipid that is not translocated by the aminophospholipid translocase (i.e., flippase), the ability of PC to promote exocytosis was demonsrated in C2C12 myoblasts expressing the glucose transporter GLUT-1 (B). Upon incubation with cells, PC switched the balance of GLUT-1 from intracellular stores (in red) compartment to the membrane (in green). Note that phosphatidylserine (PS) that accumulates into the inner leaflet thanks to the aminophospholipid translocase activity does not generate exocytosis (C: control; PC: phosphatidylcholine; PS: phosphatidylserine).

recycling is driven by the ability of cells to form intracellular vesicles. The motor force behind the creation of vesicles resides, initially, in the membrane. The membrane is composed of two leaflets but these leaflets are not randomly composed, some lipids are preferentially located within the inner leaflet (e.g., phosphatidylsérine or phosphatidylethanolamine) whereas others remain in the outer leaflets (sphygomyelin). The non random composition of the membrane is attributed to ATPdependant lipid flippases ordering the membrane [76]. The creation of such an asymmetry in the type of lipids between the two leaflets induces a change in the physical properties of the membrane with an inner leaflet being more compacted than the outer one [77] (Figure 4). This compaction cannot be stored in the membrane, requiring the cell to release this energy and one way to do this is via the creation of intracellular vesicles. Naturally, one could argue that the model suggests that too much endocytosis should deplete the plasmalemma of the cell. However this never happens as exocytosis and endocytosis are two faces of the same coin and as a result will balance each other [78]. In essence the lipid asymmetry between the two membrane leaflets permits a low cost in ATP usage and a constant and smooth recycling of the membrane.

How can this process be altered is down to how the physical properties of the membrane are affected. Let us assume that the lipid asymmetry is annihilated, endocytosis will stop. Now, if we reverse the lipid asymmetry - i.e., compact more the outer leaflet via the addition of exogenous lipid species compared to the inner leaflet; endocytosis will stop and exocytosis should be promoted [79-81]. In cells, not all receptors are displayed on the membrane, some stay within cells in endosomes or vesicles some may even recycle constantly between the membrane and the intracellular vesicles. By physically triggering membrane exocytosis it should be possible to empty all the intracellular compartments of their content leading to higher "expression" of antigens and relevant immunological molecules such as MHC and CD40. Experimentally, exocytosis can be promoted by simple incubation of phospholipids with cells such as phosphatidylcholine (PC) that is not translocated 
by the lipid flippase from the outer into the inner leaflet. In these conditions, PC can promote exocytosis by reversing the endogenous lipid asymmetry and this has already been demonstrated in myocytes by Rauch and Loughna (2005) (Figure 3).

\section{Conclusion}

Manipulation of MDDCs may lead to a more robust presentation of cancer antigens which may increase the impact of current (and very promising) syngeneic MDDC cancer vaccines.

\section{Competing interests}

The authors declare that they have no competing interests.

Authors' contributions

\begin{tabular}{|l|c|c|c|}
\hline Authors' contributions & CR & HI & NF \\
\hline Research concept and design & $\checkmark$ & -- & $\checkmark$ \\
\hline Collection and/or assembly of data & -- & $\checkmark$ & -- \\
\hline Data analysis and interpretation & $\checkmark$ & $\checkmark$ & $\checkmark$ \\
\hline Writing the article & $\checkmark$ & $\checkmark$ & $\checkmark$ \\
\hline Critical revision of the article & $\checkmark$ & -- & $\checkmark$ \\
\hline Final approval of article & $\checkmark$ & $\checkmark$ & $\checkmark$ \\
\hline Statistical analysis & -- & -- & -- \\
\hline
\end{tabular}

\section{Acknowledgement}

The review article and research within was funded by Nottingham University funding awarded to CR and NF.

\section{Publication history}

EIC: G.J. Peters, VU University Medical Center, Netherlands.

Received: 10-Aug-2013 Revised: 16-Oct-2013

Re-Revised: 24-Oct-2013 Accepted: 31-Oct-2013

Published: 16-Nov-2013

\section{References}

1. World Cancer Research Fund. 2012. | Website

2. Cancer Research UK. 2012. | Website

3. Cancer Diagnosis and Treatment: A 2021 Projection. Bupa 2012. | Pdf

4. Komarova NL and Wodarz D. Drug resistance in cancer: principles of emergence and prevention. Proc Natl Acad Sci U S A. 2005; 102:9714-9. | Article | PubMed Abstract | PubMed Full Text

5. Wodarz D and Komarova NL. Emergence and prevention of resistance against small molecule inhibitors. Semin Cancer Biol. 2005; 15:506-14. | Article I PubMed

6. Matsuo T, Nishizuka SS, Ishida K, Endo F, Katagiri H, Kume K, Ikeda M, Koeda $\mathrm{K}$ and Wakabayashi $\mathrm{G}$. Evaluation of chemosensitivity prediction using quantitative dose-response curve classification for highly advanced/relapsed gastric cancer. World J Surg Oncol. 2013; 11:11. | Article | PubMed Abstract | PubMed Full Text

7. Masica DL and Karchin R. Collections of simultaneously altered genes as biomarkers of cancer cell drug response. Cancer Res. 2013; 73:1699708. | Article | PubMed

8. Lecca P. An integrative network inference approach to predict mechanisms of cancer chemoresistance. Integr Biol (Camb). 2013; 5:458-73. | Article I PubMed

9. Huang $S$, Holzel M, Knijnenburg T, Schlicker A, Roepman P, McDermott U, Garnett M, Grernrum W, Sun C, Prahallad A, Groenendijk FH, Mittempergher L, Nijkamp W, Neefjes J, Salazar R, Ten Dijke P, Uramoto H, Tanaka F, Beijersbergen RL, Wessels LF and Bernards R. MED12 controls the response to multiple cancer drugs through regulation of TGF-beta receptor signaling. Cell. 2012; 151:937-50. | $\underline{\text { Article | PubMed }}$ Abstract I PubMed Full Text

10. Inaba K, Metlay JP, Crowley MT and Steinman RM. Dendritic cells pulsed with protein antigens in vitro can prime antigen-specific, MHC-restricted T cells in situ. J Exp Med. 1990; 172:631-40. | Article | PubMed Abstract | PubMed Full Text

11. Milling SW, Jenkins CD, Yrlid U, Cerovic V, Edmond H, McDonald V, Nassar $M$ and Macpherson $G$. Steady-state migrating intestinal dendritic cells induce potent inflammatory responses in naive CD4+ T cells. Mucosal Immunol. 2009; 2:156-65. | Article | PubMed

12. Wykes M, Pombo A, Jenkins $C$ and MacPherson GG. Dendritic cells interact directly with naive $B$ lymphocytes to transfer antigen and initiate class switching in a primary T-dependent response. $J$ Immunol. 1998; 161:1313-9. | Article | PubMed

13. Mellman I, Turley SJ and Steinman RM. Antigen processing for amateurs and professionals. Trends Cell Biol. 1998; 8:231-7. | Article | PubMed

14. Banchereau J, Briere F, Caux C, Davoust J, Lebecque S, Liu YJ, Pulendran $\mathrm{B}$ and Palucka K. Immunobiology of dendritic cells. Annu Rev Immunol. 2000; 18:767-811. I Article I PubMed

15. Lipscomb MF and Masten BJ. Dendritic cells: immune regulators in health and disease. Physiol Rev. 2002; 82:97-130. | Article | PubMed

16. Foster N, Turnbull EL and Macpherson G. Migrating lymph dendritic cells contain intracellular CD40 that is mobilized to the immunological synapse during interactions with antigen-specific T lymphocytes. J Immunol. 2012; 189:5632-7. I Article | PubMed

17. Geissmann F, Dieu-Nosjean MC, Dezutter C, Valladeau J, Kayal S, Leborgne M, Brousse N, Saeland S and Davoust J. Accumulation of immature Langerhans cells in human lymph nodes draining chronically inflamed skin. J Exp Med. 2002; 196:417-30. | Article | PubMed Abstract I PubMed Full Text

18. Chorro L, Sarde A, Li M, Woollard KJ, Chambon P, Malissen B, Kissenpfennig A, Barbaroux JB, Groves R and Geissmann F. Langerhans cell (LC) proliferation mediates neonatal development, homeostasis, and inflammation-associated expansion of the epidermal LC network. J Exp Med. 2009; 206:3089-100. | Article | PubMed Abstract | PubMed Full Text

19. Dzionek A, Fuchs A, Schmidt P, Cremer S, Zysk M, Miltenyi S, Buck DW and Schmitz J. BDCA-2, BDCA-3, and BDCA-4: three markers for distinct subsets of dendritic cells in human peripheral blood. J Immunol. 2000; 165:6037-46. | Article | PubMed

20. Grabbe S, Kampgen E and Schuler G. Dendritic cells: multi-lineal and multi-functional. Immunol Today. 2000; 21:431-3. | Article | PubMed

21. Tversky JR, Le TV, Bieneman AP, Chichester KL, Hamilton RG and Schroeder JT. Human blood dendritic cells from allergic subjects have impaired capacity to produce interferon-alpha via Toll-like receptor 9 Clin Exp Allergy. 2008; 38:781-8. I Article I PubMed Abstract I PubMed Full Text

22. Gregory SH, Sagnimeni AJ, Zurowski NB and Thomson AW. Flt3 ligand pretreatment promotes protective immunity to Listeria monocytogenes. Cytokine. 2001; 13:202-8. | Article | PubMed

23. Parajuli P, Pisarev V, Sublet J, Steffel A, Varney M, Singh R, LaFace D and Talmadge JE. Immunization with wild-type p53 gene sequences coadministered with Flt3 ligand induces an antigen-specific type $1 \mathrm{~T}$-cell response. Cancer Res. 2001; 61:8227-34. | Article | PubMed

24. Merad M, Sugie T, Engleman EG and Fong L. In vivo manipulation of dendritic cells to induce therapeutic immunity. Blood. 2002; 99:167682. | Article | PubMed

25. Lynch DH, Andreasen A, Maraskovsky E, Whitmore J, Miller RE and Schuh JC. Flt3 ligand induces tumor regression and antitumor immune responses in vivo. Nat Med. 1997; 3:625-31. | Article | PubMed

26. Borges L, Miller RE, Jones J, Ariail K, Whitmore J, Fanslow W and Lynch $\mathrm{DH}$. Synergistic action of fms-like tyrosine kinase 3 ligand and CD40 ligand in the induction of dendritic cells and generation of antitumor immunity in vivo. J Immunol. 1999; 163:1289-97. | Article | PubMed

27. Abe A, Furumoto H, Yoshida K, Kato T, Saijo Y and Irahara M. Gene 
gun-mediated skin transfection with FL gene suppresses the growth of murine fibrosarcoma. J Med Invest. 2011; 58:39-45. | Article | PubMed

28. Kreiter S, Diken M, Selmi A, Diekmann J, Attig S, Husemann Y, Koslowski $M$, Huber C, Tureci $O$ and Sahin U. FLT3 ligand enhances the cancer therapeutic potency of naked RNA vaccines. Cancer Res. 2011; 71:613242. | Article | PubMed

29. Taylor SJ, Dagger SA, Thien CB, Wikstrom ME and Langdon WY. Flt3 inhibitor AC220 is a potent therapy in a mouse model of myeloproliferative disease driven by enhanced wild-type Flt3 signaling. Blood. 2012; 120:4049-57. | Article | PubMed

30. Greystoke A, O'Connor JP, Linton K, Taylor MB, Cummings J, Ward T, Maders F, Hughes A, Ranson M, Illidge TM, Radford J and Dive C. Assessment of circulating biomarkers for potential pharmacodynamic utility in patients with lymphoma. Br J Cancer. 2011; 104:719-25. | Article | PubMed Abstract | PubMed Full Text

31. Bertho JM, Demarquay C, Frick J, Joubert C, Arenales $S$, Jacquet N, Sorokine-Durm I, Chau Q, Lopez M, Aigueperse J, Gorin NC and Gourmelon P. Level of Flt3-ligand in plasma: a possible new bioindicator for radiation-induced aplasia. Int J Radiat Biol. 2001; 77:70312. | Article | PubMed

32. Molineux G. The design and development of pegfilgrastim (PEGrmetHuG-CSF, Neulasta). Curr Pharm Des. 2004; 10:1235-44. | Article | PubMed

33. Liao F, Rabin RL, Smith CS, Sharma G, Nutman TB and Farber JM. CCchemokine receptor 6 is expressed on diverse memory subsets of T cells and determines responsiveness to macrophage inflammatory protein 3 alpha. J Immunol. 1999; 162:186-94. | Article | PubMed

34. Dranoff G, Jaffee E, Lazenby A, Golumbek P, Levitsky H, Brose K, Jackson $V$, Hamada H, Pardoll D and Mulligan RC. Vaccination with irradiated tumor cells engineered to secrete murine granulocyte-macrophage colony-stimulating factor stimulates potent, specific, and long-lasting anti-tumor immunity. Proc Natl Acad Sci U S A. 1993; 90:3539-43. | Article | PubMed Abstract | PubMed Full Text

35. Choi $Y$ and Kim CW. Antitumor effects of combined granulocyte macrophage colony stimulating factor and macrophage inflammatory protein-3 alpha plasmid DNA. Cancer Sci. 2010; 101:2341-50. | Article | PubMed

36. Shields JD, Fleury ME, Yong C, Tomei AA, Randolph GJ and Swartz MA. Autologous chemotaxis as a mechanism of tumor cell homing to lymphatics via interstitial flow and autocrine CCR7 signaling. Cancer Cell. 2007; 11:526-38. | Article | PubMed

37. Shields JD, Kourtis IC, Tomei AA, Roberts JM and Swartz MA. Induction of lymphoidlike stroma and immune escape by tumors that express the chemokine CCL21. Science. 2010; 328:749-52. | Article | PubMed

38. Homann D, Jahreis A, Wolfe T, Hughes A, Coon B, van Stipdonk MJ, Prilliman KR, Schoenberger SP and von Herrath MG. CD40L blockade prevents autoimmune diabetes by induction of bitypic NK/DC regulatory cells. Immunity. 2002; 16:403-15. | Article | PubMed

39. Chan CW, Crafton E, Fan HN, Flook J, Yoshimura K, Skarica M, Brockstedt D, Dubensky TW, Stins MF, Lanier LL, Pardoll DM and Housseau F. Interferon-producing killer dendritic cells provide a link between innate and adaptive immunity. Nat Med. 2006; 12:207-13. | Article | PubMed

40. Souza AP, Bonorino C, Muraro SP and Rodrigues LC, Jr. Interleukin-21 expanded NKDC in vitro reduces the B16F10 tumor growth in vivo. Cytokine. 2013; 61:154-60. | Article | PubMed

41. Vosshenrich CA, Lesjean-Pottier S, Hasan M, Richard-Le Goff O, Corcuff E, Mandelboim O and Di Santo JP. CD11cloB220+ interferon-producing killer dendritic cells are activated natural killer cells. J Exp Med. 2007; 204:2569-78. | Article | PubMed Abstract | PubMed Full Text

42. Jiang $\mathrm{H}$, Lin JJ, Su ZZ, Goldstein NI and Fisher PB. Subtraction hybridization identifies a novel melanoma differentiation associated gene, mda-7, modulated during human melanoma differentiation, growth and progression. Oncogene. 1995; 11:2477-86. | PubMed

43. Jiang H, Su ZZ, Lin JJ, Goldstein NI, Young CS and Fisher PB. The melanoma differentiation associated gene mda-7 suppresses cancer cell growth. Proc Natl Acad Sci U S A. 1996; 93:9160-5. | Article | PubMed

\section{Abstract | PubMed Full Text}

44. Patani N, Douglas-Jones A, Mansel R, Jiang W and Mokbel K. Tumour suppressor function of MDA-7/IL-24 in human breast cancer. Cancer Cell Int. 2010; 10:29. | Article | PubMed Abstract | PubMed Full Text

45. Xu S, Oshima T, Imada T, Masuda M, Debnath B, Grande F, Garofalo A and Neamati N. Stabilization of MDA-7/IL-24 for colon cancer therapy. Cancer Lett. 2013; 335:421-30. | Article | PubMed

46. Whitaker EL, Filippov VA and Duerksen-Hughes PJ. Interleukin 24: mechanisms and therapeutic potential of an anti-cancer gene. Cytokine Growth Factor Rev. 2012; 23:323-31. | Article | PubMed

47. Chada S, Sutton RB, Ekmekcioglu S, Ellerhorst J, Mumm JB, Leitner WW, Yang HY, Sahin AA, Hunt KK, Fuson KL, Poindexter N, Roth JA, Ramesh R, Grimm EA and Mhashilkar AM. MDA-7/IL-24 is a unique cytokine--tumor suppressor in the IL-10 family. Int Immunopharmacol. 2004; 4:649-67. Article | PubMed

48. Yu X, Xia W, Zhang T, Wang H, Xie Y, Yang J and Miao J. Enhanced cytotoxicity of IL-24 gene-modified dendritic cells co-cultured with cytokine-induced killer cells to hepatocellular carcinoma cells. Int $J$ Hematol. 2010; 92:276-82. | Article | PubMed

49. Chang JM, Hung LM, Chyan YJ, Cheng CM and Wu RY. Carthamus tinctorius Enhances the Antitumor Activity of Dendritic Cell Vaccines via Polarization toward Th1 Cytokines and Increase of Cytotoxic T Lymphocytes. Evid Based Complement Alternat Med. 2011; 2011:274858. | Article | PubMed Abstract | PubMed Full Text

50. Shi X, Ruan D, Wang Y, Ma L and Li M. [Anti-tumor activity of safflower polysaccharide (SPS) and effect on cytotoxicity of CTL cells, NK cells of T739 lung cancer in mice]. Zhongguo Zhong Yao Za Zhi. 2010; 35:215-8. I PubMed

51. Huang YK, Zheng Z and Qiu F. Polyinosinic-cytidylic acid as an adjuvant on natural killer- and dendritic cell-mediated antitumor activities. Tumour Biol. 2013; 34:1615-23. | Article | PubMed

52. Ingalls RR and Golenbock DT. CD11c/CD18, a transmembrane signaling receptor for lipopolysaccharide. J Exp Med. 1995; 181:1473-9. | Article | PubMed Abstract | PubMed Full Text

53. Herbst B, Kohler G, Mackensen A, Veelken H and Lindemann A. GMCSF promotes differentiation of a precursor cell of monocytes and Langerhans-type dendritic cells from CD34+ haemopoietic progenitor cells. Br J Haematol. 1998; 101:231-41. | Article | PubMed

54. Forte G, Rega A, Morello S, Luciano A, Arra C, Pinto A and Sorrentino R. Polyinosinic-polycytidylic acid limits tumor outgrowth in a mouse model of metastatic lung cancer. J Immunol. 2012; 188:5357-64. | Article | PubMed

55. Lim SN, Kuhn S, Hyde E and Ronchese F. Combined TLR stimulation with Pam3Cys and Poly I: C enhances Flt3-ligand dendritic cell activation for tumor immunotherapy. J Immunother. 2012; 35:670-9. | Article | PubMed

56. Sallusto F and Lanzavecchia A. Efficient presentation of soluble antigen by cultured human dendritic cells is maintained by granulocyte/ macrophage colony-stimulating factor plus interleukin $\mathbf{4}$ and downregulated by tumor necrosis factor alpha. J Exp Med. 1994; 179:1109-18. | Pdf | PubMed Abstract | PubMed Full Text

57. Sallusto F, Cella M, Danieli C and Lanzavecchia A. Dendritic cells use macropinocytosis and the mannose receptor to concentrate macromolecules in the major histocompatibility complex class II compartment: downregulation by cytokines and bacterial products. $J$ Exp Med. 1995; 182:389-400. | Pdf | PubMed Abstract | PubMed Full Text

58. Mutamba S, Allison A, Mahida Y, Barrow P and Foster N. Expression of IL1 Rrp2 by human myelomonocytic cells is unique to DCs and facilitates DC maturation by IL-1F8 and IL-1F9. Eur J Immunol. 2012; 42:607-17. I Article I PubMed

59. Shortman K and Naik SH. Steady-state and inflammatory dendritic-cell development. Nat Rev Immunol. 2007; 7:19-30. | Article | PubMed

60. Naik SH. Demystifying the development of dendritic cell subtypes, a little. Immunol Cell Biol. 2008; 86:439-52. | Article | PubMed 
Rauch et al. Journal of Cancer Therapeutics \& Research 2013,

61. O'Neill DW, Adams S and Bhardwaj N. Manipulating dendritic cell biology for the active immunotherapy of cancer. Blood. 2004; 104:223546. | Article | PubMed

62. Schuler G, Schuler-Thurner B and Steinman RM. The use of dendritic cells in cancer immunotherapy. Curr Opin Immunol. 2003; 15:138-47. | Article | PubMed

63. Sabado RL and Bhardwaj N. Directing dendritic cell immunotherapy towards successful cancer treatment. Immunotherapy. 2010; 2:37-56. Article | PubMed Abstract | PubMed Full Text

64. Ridgway D. The first $\mathbf{1 0 0 0}$ dendritic cell vaccinees. Cancer Invest. 2003; 21:873-86. | Article | PubMed

65. Ridolfi R, Petrini M, Fiammenghi L, Stefanelli M, Ridolfi L, Ballardini M, Migliori $G$ and Riccobon $A$. Improved overall survival in dendritic cell vaccination-induced immunoreactive subgroup of advanced melanoma patients. J Trans/ Med. 2006; 4:36. | Article | PubMed Abstract | PubMed Full Text

66. Lesterhuis WJ, De Vries IJ, Schreibelt G, Schuurhuis DH, Aarntzen EH, De Boer A, Scharenborg NM, Van De Rakt M, Hesselink EJ, Figdor CG, Adema GJ and Punt CJ. Immunogenicity of dendritic cells pulsed with CEA peptide or transfected with CEA mRNA for vaccination of colorectal cancer patients. Anticancer Res. 2010; 30:5091-7. | Article | PubMed

67. Morse MA, Clay TM, Hobeika AC, Osada T, Khan S, Chui S, Niedzwiecki $D$, Panicali D, Schlom J and Lyerly HK. Phase I study of immunization with dendritic cells modified with fowlpox encoding carcinoembryonic antigen and costimulatory molecules. Clin Cancer Res. 2005; 11:301724. | Article | PubMed

68. Hao X, Shao Y, Ren X, Liu H, Xu Q, Li H, Zhang P, An X and Ren B. Induction of specific CTL by MAGE-3/CEA peptide-pulsed dendritic cells from HLA-A2/A24(+) gastrointestinal cancer patients. J Cancer Res Clin Oncol. 2002; 128:507-15. | Article | PubMed

69. Lu B, Liu BY, Zhang Y, Chen XH, Zhu ZG, Yin HR and Lin YZ. [Inhibitory effect of dendritic cells pulsed with MAGE-3 peptide on transplanted murine gastric cancer in mice]. Zhonghua Yi Xue Za Zhi. 2005; 85:2120-3. I PubMed

70. Koski GK, Koldovsky U, Xu S, Mick R, Sharma A, Fitzpatrick E, Weinstein $\mathrm{S}$, Nisenbaum H, Levine BL, Fox K, Zhang P and Czerniecki BJ. A novel dendritic cell-based immunization approach for the induction of durable Th1-polarized anti-HER-2/neu responses in women with early breast cancer. J Immunother. 2012; 35:54-65. | Article I PubMed Abstract | PubMed Full Text

71. Ferrantini M, Capone I and Belardelli F. Dendritic cells and cytokines in immune rejection of cancer. Cytokine Growth Factor Rev. 2008; 19:93107. | Article | PubMed

72. Baumgartner JM, Jordan KR, Hu LJ, Wilson CC, Banerjee A and McCarter $\mathrm{MD}$. DC maturation and function are not altered by melanoma-derived immunosuppressive soluble factors. J Surg Res. 2012; 176:301-8. | Article I PubMed

73. Kuo PL, Hung JY, Huang SK, Chou SH, Cheng DE, Jong YJ, Hung CH, Yang CJ, Tsai YM, Hsu YL and Huang MS. Lung cancer-derived galectin-1 mediates dendritic cell anergy through inhibitor of DNA binding 3/IL-10 signaling pathway. J Immunol. 2011; 186:1521-30. I Article I PubMed

74. Thumann P, Moc I, Humrich J, Berger TG, Schultz ES, Schuler G and Jenne L. Antigen loading of dendritic cells with whole tumor cell preparations. J Immunol Methods. 2003; 277:1-16. | Article | PubMed

75. Dhodapkar MV, Steinman RM, Sapp M, Desai H, Fossella C, Krasovsky J, Donahoe SM, Dunbar PR, Cerundolo V, Nixon DF and Bhardwaj N. Rapid generation of broad T-cell immunity in humans after a single injection of mature dendritic cells. J Clin Invest. 1999; 104:173-80. | Article | PubMed Abstract | PubMed Full Text

76. Devaux PF, Lopez-Montero I and Bryde S. Proteins involved in lipid translocation in eukaryotic cells. Chem Phys Lipids. 2006; 141:119-32. | Article I PubMed

77. Rauch $C$ and Farge E. Endocytosis switch controlled by transmembrane osmotic pressure and phospholipid number asymmetry. Biophys J. 2000; 78:3036-47. | Article | PubMed Abstract | PubMed Full Text

78. Rauch C, Pluen A, Foster N, Loughna P, Mobasheri A, Lagadic-Gossmann
$D$ and Counillon L. On some aspects of the thermodynamic of membrane recycling mediated by fluid phase endocytosis: evaluation of published data and perspectives. Cell Biochem Biophys. 2010; 56:7390. I Article I PubMed

79. Baba T, Rauch C, Xue M, Terada N, Fujii Y, Ueda H, Takayama I, Ohno $S$, Farge E and Sato SB. Clathrin-dependent and clathrin-independent endocytosis are differentially sensitive to insertion of poly (ethylene glycol)-derivatized cholesterol in the plasma membrane. Traffic. 2001; 2:501-12. | Article I PubMed

80. Rauch C, Brunet AC, Deleule J and Farge E. C2C12 myoblast/osteoblast transdifferentiation steps enhanced by epigenetic inhibition of BMP2 endocytosis. Am J Physiol Cell Physiol. 2002; 283:C235-43. | Article | PubMed

81. Rauch C and Loughna P. C2C12 skeletal muscle cells exposure to phosphatidylcholine triggers IGF-1 like-responses. Cell Physiol Biochem. 2005; 15:211-24. | Article | PubMed

\section{Citation:}

Rauch C, Ibrahim H and Foster N. Membranes, molecules and biophysics: enhancing monocyte derived dendritic cell (MDDC) immunogenicity for improved anti-cancer therapy. J Cancer Ther Res. 2013; 2:20.

http://dx.doi.org/10.7243/2049-7962-2-20 